\title{
Socio-Political Conditions for Christians in Egypt
}

\author{
Shaul M. Gabbay, (PhD) \\ Director, Global Research Institute, \\ Posner Center for International Development, USA
}

Doi:10.19044/esj.2018.v14n20p144 URL:http://dx.doi.org/10.19044/esj.2018.v14n20p144

\begin{abstract}
For those who have studied the history of religious tensions in Egypt, the current rising tide of violence against Christians in the country should come as no surprise. Persecution of Christians in Egypt dates back for centuries. In recent years - particularly during the past decade - we have witnessed a greater interest in understanding the violence, not only in academia, but among the interested general population as well. This has led to an upsurge in academic writings and in media articles discussing the issue. After a thorough literature review, I have discovered that many of the pieces focus on the empirical, while often neglecting the normative. While empiricism is important for any research endeavor, this paper seeks to focus more on the narratives on the ground. As a sociologist for three decades, I have worked closely with the Egyptian Christian immigrant community in the U.S. and have regularly been called to testify in asylum courts across the U.S. regarding the issues of religious intolerance in Egypt. Over the years, I have conducted countless interviews with these individuals. As such, I have used their personal stories as a starting point for my academic inquiries. As a case study, I have selected three personal narratives to include in this analysis. All of the individuals' names have been changed in order to safeguard their identity. For this paper, I have specifically chosen individuals from different backgrounds, genders, education levels, social standings, and geographical location. In doing so, I was able to piece together a larger narrative that demonstrates how the persecution of Christians in Egypt is not limited to one group or another-it is widespread throughout Egyptian society. In the end, I was able to discover that each of the individuals suffered in different ways. However, they all suffered given one basic commonality — being Christian in Egypt.
\end{abstract}

Keywords: Egypt, Christianity, extremism 


\section{Introduction: The Cases:}

The cases meticulously chosen for this paper include the narratives of three individuals who have been persecuted for their Christian beliefs. The reader will discover that while their backgrounds differ, the common thread connecting each one of them is how they at first learned to cope with abuse, suffered severe discrimination and violence, and then choosing to seek refuge in the United States. Below are summaries of the cases that led to the development of this paper. Again, each of the names has been changed.

\section{Case 1: Mr. Lukman:}

Mr. Lukman was born in Omraneyah, Giza, Egypt. Mr. Lukman is a Coptic Christian. According to Mr. Lukman, he has suffered persecution due to his religion. In his own words, Mr. Lukman described the incidents he endured as a Coptic Christian in Egypt:

My whole life in Egypt was marked by harassment, persecution, discrimination, threats, attacks, limited opportunities and the constant risk of imprisonment, harm, torture or death due to my religion. I am a Coptic Christian and in Egypt, Christians face constant mistreatment, threats and persecution. As part of our faith, we tattoo a blue cross on our wrists and I have this cross tattooed on my right wrist, which makes me even more of a target for those who persecute and harm Christians. I was beat[sic] by my classmates in school and mistreated, harmed and persecuted throughout my life, from school to work to daily life activities and even during leisure activities. For example, I was beat[sic] savagely in Hurghada, at the Red Sea, where I was working, by a tea seller and his family at my workplace stemming from an argument and unfair treatment because I was Christian. I still have a scar on my head from that beating. While going to a wedding in Luxor, in the south of the country, I was the only Christian on the minivan we were traveling in, and at a checkpoint I was pulled off the van, and then arrested, detained and threatened with imprisonment after the police saw my blue cross. The mistreatment in Egypt due to being Christian is constant, from being called names while buying food and riding public transport to actual physical violence. My Christian family, friends and colleagues also experience mistreatment on a daily basis. That is why I left Egypt: I wanted a better life for my children and I knew if we stayed in Egypt, their lives would be marked by the harm and persecution I experienced, with no protection and willful blindness and direct harm from the government." 


\section{Case 2: Mr. Masud:}

Mr. Masud, a convert to Christianity, was born into a Muslim family in Kom-Hamada, Egypt. Growing up in a rural area, Mr. Masud stated that Islam was strictly practiced and that some of his family members adhered to the conservative Salafist movement. By the time Mr. Masud became a teenager his father forced him to attend weekly required prayer sessions. According to Mr. Masud, he didn't like the sessions, and his father allowed him to attend an overnight youth group instead.

Mr. Masud stated that during the meetings, which included varying religious activities, he began to question the doctrines being taught. As a result of his questions, he was expelled from the group. According to Mr. Masud, once his father found out he beat him severely. In his own words, Mr. Masud describes the consequences of his expulsion from the youth group as follows:

As a result my father immediately started hitting me in the face and beating me because of my conduct. He started kicking me with his foot and I was locked in my room. I was waiting for my mother to come home and rescue me, but after three hours my mother came home and I heard my father telling her what had happened and thereafter my mother started cursing me too, and she opened the door to my room and saw that I was bleeding from my father's beating and she started kicking me and slapping my face too saying that I have evil in me. She called the Eman [sic] asking what they should do. The Eman said that I have an evil mind and need to beaten in order for the evil soul to leave my body and mind. They in fact brought some women who told me that she was a doctor to get the evil soul out of my head and body. My father came with two other men and strapped me to the bed and the lady grabbed a blade and cut the top of my head in order for me to bleed out so the evil runs out of the cuts. She did that and I was crying. After an hour she finished cutting my head and blood was all over my eyes and face. Thereafter I restrained myself to ask about religious issues but still have the marks of the wounds in my head. Mr. Masud's uncle threatened to kill him by, "slicing me in pieces and putting me in a garbage bag.

\section{Case 3: Ms. Shani:}

Ms. Shani was born in Cairo, Egypt. Born into a Coptic Orthodox Christian family, Ms. Shani has close ties to the Church, and has priests and monks in the family. Growing up, Ms. Shani states that she often experienced discrimination due to her religious beliefs. For example, while in high school, Ms. Shani notes that she received excellent academic marks, but that her teachers treated her with disdain because she was a Christian. 
Throughout her life in Egypt Ms. Shani stated that she was treated similarly, not just by teachers and fellow students, but by others in the community as well. Ms. Shani recounted a particularly harrowing incident while serving at the Church. Her description is as follows:

I was serving at St. Mary Church. The kids in my class ranged from six to ten years old in age. One day I was sitting with my class in the small church on the first floor, when suddenly a man entered the main entrance of the church with a thick iron stick in his hand. He headed to the altar and started to destroy it while shouting "Allahu Akbar, Allahu Akbar!" (God is great, God is great!). The kids were screaming and I was afraid that he would harm them. The other servants surrounded him and eventually they had control over him, but only after he had destroyed the altar.

Ms. Shani stated that she and her fellow servants called the police, but that they did not offer any help, only saying that they should blame themselves for keeping the main entrance open and for leaving the altar unattended. With no other recourse, the members of St. Mary's took the appropriate precautions; however, they were unable to protect the church and its attendees. Two years following the first incident, a large group of members from the Muslim Brotherhood and Salafists forcibly entered the church and began to set fire to the building. In her statement, Ms. Shani stated:

[T] hey forcibly entered the church at 9:00 PM and destroyed everything in it, such as the altar, the Coptic icons, and all the tools and benches. They also slaughtered a man named Salah, because he refused to denounce his faith and convert to Islam. After they murdered him, the [sic] left his body to be completely burned with the church.

Following this incident, Ms. Shani states that she began spending more and more time at home, fearing future attacks. However, she felt it necessary to help in the rebuilding of her community's destroyed church. According to Ms. Shani, soon after the restoration was completed, she started receiving death threats from a member of the Muslim Brotherhood.

Ms. Shani stated that while serving as a youth leader at the church, she attempted to help one of the female attendees, named Ms. Fahmi. According to Ms. Shani, Ms. Fahmi approached her and told her that she had fallen in love with a Muslim man. Ms. Fahmi told Ms. Shani that her suitor asked her to run away from home and to marry him. Ms. Shani told Ms. Fahmi that she would look into the matter further, and she asked to priest of the church to help her in the investigation. Upon their joint investigation, Ms. Shani found out that Ms. Fahmi's suitor, Mr. Abdel was an active member of the Muslim Brotherhood and that he had previously spent three years in jail after having been accused of partaking in "terrorist activities." Additionally, Ms. Shani 
discovered that Mr. Abdel had intentions of forcing Ms. Fahmi to convert to Islam.

When Ms. Shani discussed her findings with Ms. Fahmi, Ms. Fahmi confirmed that Mr. Abdel had indeed asked her to renounce Christianity, and that she was becoming increasingly afraid of him. According to Ms. Shani, she tried her best to help Ms. Fahmi calm down, and she convinced her to meet with the priest. During the meeting with the priest, Ms. Shani, and Ms. Fahmi, it was agreed that Ms. Fahmi should keep in contact with Mr. Abdel as to not raise any suspicion, and to buy them time in order to secure a safe place for Ms. Fahmi to hide.

Subsequently, Ms. Shani kept in constant contact with Ms. Fahmi. Ms. Fahmi told her that Mr. Abdel was becoming suspicious, and that he began asking questions about her relationship with Ms. Shani. Eventually, Ms. Shani learned that Mr. Abdel was having her followed. It was soon after that Ms. Shani began receiving anonymous phone messages warning her to stay away from Ms. Fahmi. Once again, Ms. Shani consulted her priest. The priest told Ms. Shani that he had finally secured a safe place for Ms. Fahmi to escape. Ms. Shani went directly to Ms. Fahmi and told her to prepare to leave. Ms. Shani took Ms. Fahmi to a local monastery.

According to Ms. Shani, on August 1, 2013, Mr. Abdel approached her while she was returning from work. Ms. Shani stated that Mr. Abdel asked her about the whereabouts of Ms. Fahmi. She responded by stating that she did not know. Upon hearing this, Mr. Abdel began to beat Ms. Shani and told her that he would kidnap and kill her if she did not call him within two days and tell him where Ms. Fahmi was hiding.

Following the attack and threats, Ms. Shani rushed to her parents' house. They took her to the hospital so that she could receive treatment for her wounds. Afterwards, they told her that she was no longer safe in the neighborhood and told her to seek refuge at her aunt's home, which was two hours away. Even though Ms. Shani heeded her father's advice and went to stay with her aunt, the threats did not end, and she began to realize that she was no longer safe anywhere in Egypt,

At this point, I realized that living in Egypt had become impossible and it was now a matter of life and death. On August 3, 2013, my aunt, who lives in America, found out about what had happened to me from my mother, she called me at my other aunt's home and told me that I had to leave Egypt and come to America. I agreed that I had to leave Egypt as soon as possible. I called Egypt air [sic] the same day and reserved a ticket for October 4, 2013, just to give myself a little time to resign from work and say goodbye to my family. 
In the aforementioned cases, there are a number of interesting points. First in Mr. Lukman's case, we noted the struggles of growing up as a Christian in Egypt. I include Mr. Lukman's narrative because it focuses on the more general aspects of the issues facing Christians living in Egypt. In the case presented by Mr. Masud, we see additional issues. It becomes apparent that Christians do not only face persecution and violence at the hands of the government and larger society, but also face threats from their own family members. In Ms. Shani's case, there is the additional factor of gender. Not only was Ms. Shani targeted for being a Christian, she faced the difficulty of being a second-class citizen in patriarchal Egypt. The fears expressed by Mr. Lukman, Mr. Masud, and Ms. Shani are unfortunately not uncommon in Egypt.

Even under the "best" circumstances, Egypt has always been inhospitable to religious freedom. For example, despite the government's official statements supporting religious freedom -both before and after the so called "Arab Spring Revolution" - the past decade has witnessed an increase in religiously motivated violence. For the most part, its vehemence has been directed at the minority Coptic Christian community.

Since the "Arab Spring Revolution", religious minorities have been fleeing the country in droves. As U.S. Congressman Frank Wolf describes, they "fear for their future" ("Egyptian Copts seek Russian refuge," 2013). As this analysis will further document and explain, Rep. Wolf is not alone in his worries concerning Egypt's treatment of religious minorities. BBC World News noted that since the Revolution, thousands of Copts have fled the country. In 2018, Open Doors International degraded Egypt to number 17 on its World Watch List for religious freedom ("World Watch List | Countries Where Christianity is Illegal \& Oppressed," n.d.).

While many in the international community were optimistic about Egypt's prospects following the ouster of President Mubarak, we were all quick to learn about the struggles of an emerging democracy. During the past six years, we have witnessed a whirlwind of change. First, we saw the election of President Morsi - a member of the now outlawed Muslim Brotherhood only to see him ousted and replaced by General al-Sisi, Egypt's current President.

During his rule - which continues to this day - President al-Sisi has draconically presided over the enactment of "protest laws" that have served as a justification for the persecution of any individual who opposes his government. As will be documented in this analysis, this has left Egypt's opposition community paralyzed - as its leaders have been either murdered, imprisoned, or "disappeared." As elections are to take place in the spring of 2018, the Egyptian government has been saddled with credible accusations of the use of torture against its enemies - either real or perceived. 


\section{Christians and Religious Intolerance in Egypt:}

Paganism was the original religion of Egypt. It existed when Christianity was brought to Egypt during the reign of the Roman Emperor Nero in the first century CE (Common Era). In the following decades Christianity spread throughout the country and remained strong for six hundred years. The Muslim Conquest of Egypt in $641 \mathrm{CE}$ introduced Islam to Egypt, and the two religions co-existed side by side for several more centuries. However, Muslims began persecuting Christians, identified now as Orthodox Coptic Christians, in the $11^{\text {th }}$ century:

There were restrictions on repairing old Churches and building new ones, on testifying in court, on public behavior, on adoption, on inheritance, on public religious activities, and on dress codes. Slowly but steadily, by the end of the 12th century, the face of Egypt changed from a predominantly Christian to a predominantly Muslem [sic] country and the Coptic community occupied an inferior position and lived in some expectation of Muslim hostility, which periodically flared into violence ("Encyclopedia Coptica: The Christian Coptic Orthodox Church of Egypt," n.d.)

The position of the Copts - as Egyptian Christians are known - began to improve early in the $19^{\text {th }}$ century under the stability and tolerance of Muhammad Ali's dynasty. In the $20^{\text {th }}$ century Copts tried repeatedly to encourage the practice of tolerance and cooperation between various religions in Egypt. However, in recent decades a new movement toward Islamic fundamentalism emerged within Islam inside Egypt and elsewhere. In Egypt, the Muslim Brotherhood, grew increasingly vocal and violent, and was in fact responsible for the death of Egyptian President Anwar Sadat in 1979. Since that time many Muslims in Egypt have shown growing intolerance not only toward Christians, but also toward Muslims who do not agree with Islamic fundamentalism and political Islam.

In terms of religion, Egypt presents a seemingly daunting case. Despite "official" claims that Egypt is a religiously tolerant country, the opposite is actually true. With even a rudimentary investigation of religious practices in Egypt, one will find that non-Muslims are continually faced with persecution. This includes not only Christians, but also non-believers such as atheists.

In recent years, there has been a push to target "non-believers" in Egypt. These individuals have been frequently targeted for crimes of blasphemy, which can be translated into "crimes against the state." Perhaps the most widely known case is that of Alber Saber, an atheist blogger who was sentenced to three years in prison for crimes of blasphemy and contempt of religion ("Egypt blogger guilty of blasphemy," 2012). Citing a study from the 
International Humanist and Ethical Union, Reuters succinctly explains the situation non-Muslims face in Egypt as well as in the rest of the Muslim world: Atheists and other religious skeptics suffer persecution or discrimination in many parts of the world and in at least seven nations can be executed if their beliefs become known, according to a report issued on Monday. The study, from the International Humanist and Ethical Union (IHEU), showed that "unbelievers" in Islamic countries face the most severe sometimes brutal - treatment at the hands of the state and adherents of the official religion... In a range of other countries - such as Bangladesh, Egypt, Indonesia, Kuwait and Jordan publication of atheist or humanist views on religion are totally banned or strictly limited under laws prohibiting "blasphemy." ("Atheists around world suffer persecution, discrimination: report," 2012)

Without question, non-believers represent a persecuted group in Egypt. As more and more information becomes available concerning the treatment of atheists, a more vivid portrait that truly represents the oppression religious minorities face in Egypt has emerged.

As noted earlier, the most commonly reported concern is that of the conditions facing Christians in Egypt. Not only has the issue of Christianity in Egypt been more frequently reported in the media, it has also been well documented and researched within the academic community. Christians are essentially categorized as "non-believers," and face many, if not all, of the same consequences.

Many scholars who study the rise of religious intolerance and persecution in Egypt and in other Islamic oriented countries agree that its threats to Christians by fundamentalist Muslims are increasingly more dangerous. However, persecution of Christians in Egypt is not limited to random or planned acts by fundamentalists. Academics, journalists, human rights groups, and the U.S. State Department concur that, as one scholar put it:

The Christians are persecuted by radical Islamic groups, by the abusive practices of local police and security forces, and by discriminatory and restrictive Egyptian Government policies. The result is that while Christians are generally able to practice their faith, increasingly they do so in a climate of fear. (Religious Intolerance in Egypt, n.d)

The U.S. State Department notes that religious freedom is deteriorating throughout Egypt:

The constitution describes freedom of belief as 'absolute' but only provides adherents of Islam, Christianity, and Judaism the 
right to practice their religion freely and to build houses of worship. The government does not recognize conversion from Islam by citizens born Muslim to any other religion and imposes legal penalties on Muslim-born citizens who convert. While there is no legal ban on efforts to proselytize Muslims, the government uses the penal code's prohibition of 'denigrating religions' to prosecute those who proselytize publicly, often adopting an overly expansive interpretation of denigration, according to human rights groups. The constitution specifies Islam as the state religion and the principles of sharia as the primary source of legislation... Religious minorities continued to face significant threats of sectarian violence according to religious and human rights groups. One Muslim family reportedly killed a family member for her alleged conversion to Christianity. Individuals accused of denigration of religion often faced social intolerance and, in some cases, violence. ("International Religious Freedom Report for 2016," n.d.)

The Report also notes that along with discrimination against Christians in Egypt, the past ten years have been marked by an atmosphere of increasing sectarian conflict, which continues to be an increasing concern for police. For example, the report states that in November 2008 an unlicensed Coptic church was attacked and burned by a mob in Cairo; and on June 29, 2009, a sectarian clash erupted in Boshra when Christians were prevented from praying in an unlicensed church. On October 24, 2009, a Coptic Christian was arrested and held for two days for "praying without a license," after requesting a priest to visit his sick father, who had recently suffered a stroke. Police were concerned that this incident could cause sectarian clashes among Muslim neighbors and remanded the Coptic Christian for not obtaining permission prior to the prayer (Abdelmassih, 2009). Then, on January 6, 2010, six Copts and one security guard were killed in a drive-by shooting outside St. John's Church following a Coptic Midnight Mass (The Associated Press, 2010).

The dismal situation facing Christians in Egypt during 2008 and 2009, deteriorated further in 2010 and 2011. Succinctly highlighting a series of major attacks on Christians during that period, Paul Marshall, a senior research fellow at the Hudson Institute's Center for Religious Freedom, noted the following:

Religion-related violent attacks on Copts are certainly not new - indeed, they are endemic. There are dozens each year, including by the security forces. For example, on November 24, 2010, security forces attacked Saint Mary's Coptic Church in Giza, Cairo, to stop construction work on an extension to the 
church's community center. Police surrounded the site at 3 A.M., while Coptic men were working on the roof and 200 people were keeping vigil inside the church. The security forces used tear gas, rubber bullets, and live ammunition: Four Copts were killed and at least 50 wounded, many seriously. At least 200 Christians were arrested at the scene or nearby, and were denied access to lawyers. On January 6, 2010, in Nag Hamadi, churchgoers leaving a midnight mass on the eve of Coptic Christmas were sprayed with automatic rifle fire from passing cars. Seven people were killed and others were wounded, three seriously" ("Attacks on Egypt's Copts Escalate | National Review," 2011).

The first month of 2011 continued to demonstrate the vulnerability of Coptic Christians living in Egypt. Almost exactly a year following the massacre in Nag Hamadi, the al-Qidiseen church in Alexandria was bombed during a New Year's mass on January 1, 2011. The bombing, which left more than 20 dead and over 100 severely wounded, marked the deadliest attack specifically directed at Christians since the year 2000. This incident however, would only be sadly trumped by the October 2011 attack on the state television and radio building Maspero.

Mariz Tadros, writing for the Middle East Research and Information Project, documented the incident as follows:

On Sunday, October 9, security forces deployed tear gas, live bullets and armored vehicles in an effort to disperse peaceful protesters in downtown Cairo. Joined by Muslim sympathizers, thousands of Coptic Christians had gathered that afternoon in front of the capital's state television and radio building, known as Maspero, and in many other parts of Egypt, to protest the burning of a church in the Upper Egyptian village of al-Marinab. A few days earlier, their initial demonstrations had also been met with violence. What happened next, however, was worse than any single incident of state violence in January and February: Captured live by the cameras of the al-'Arabiyya satellite channel, armored personnel carriers bearing army markings sped toward the protesters, at one point bumping cumbrously over curbs and a sidewalk, and crushed several people to death underneath their massive treads. By night's end, 17 demonstrators were dead, and 300 more injured, some in critical condition. The death toll is now at least 25 and counting. Furthermore, the army's claim to fame during the January-February popular uprising -- that it would not, under any circumstances, harm 
Egyptian civilians -- has now been given the definitive lie.

("Egypt's Bloody Sunday | Middle East Research and Information Project).

Since 2011, conditions facing Christians have only deteriorated. The latter half of 2012 and the first half of 2013 witnessed continued violence and persecution directed at the Christian community. For example, on December 23, 2012 a thirteen year-old Christian girl was abducted near Alexandria, and was held captive for nine days ("Egyptian Christian Girl, 13, Abducted By Muslims," n.d.).

According to Persecution.org, this incident only demonstrated the growing trend of kidnapping, assault, rape, and forced conversions of Egyptian Christian women and girls ("Christian Girl Abducted In Egypt | Persecution," 2013). On February 17, 2013 Muslims stormed a Christian Church in Fayoum Province, setting fire to the building and destroying several sacred religious icons. This incident came on the heels of a similar attack in January 2013, also in Fayoum ("Muslim Villagers in Egypt Attack Church Morningstar News," 2013). Violence against Christians continued into March 2013. According to the Associated Press on March 19, 2013, Muslims extended their attacks to include Christian businesses and shops (The Washington Post, 2013).

Such continued violent attacks have prompted serious international concern. After a visit to Egypt in March 2013, U.S. Congressman Frank Wolf stated that Christians in Egypt fear for their lives, especially following the uprising:

Wolf says that many churches have been desecrated, and no permits to build new churches have been granted since the January 2011 uprising. The congressman met also with Bishop Anba Moussa, a close advisor to Coptic Pope TLukmanros II, who admitted the Coptic Christians 'fear for their future. ("Republican Congressman Frank Wolf: Coptic Christians Fear for Their Future in Morsi's Egypt," 2013)

The statements made by Congressman Wolf were highlighted not only by international watch groups such as Persecution.org, but also by prominent international news agencies. According to BBC World News since the revolution, thousands of Egyptian Christians have fled the country out of fear for their lives ("Egyptian Copts seek Russian refuge," 2013). Additionally, CBS's 60 Minutes reported that 2013 marked the worst year for Copts in Egypt in recent history:

The ongoing political violence in Egypt has led to unprecedented attacks on the county's Coptic Christian minority, the worst in their history. Copts who make up roughly 10 percent of the Egyptian population, were the 
target of revenge by Muslim mobs this summer after Egypt's first Islamist president was overthrown in a military coup. Over 40 Christian churches all over Egypt were gutted by arson and looted - some over a thousand years old and full of priceless relics. Copts have also been murdered in ongoing sectarian violence. ("Persecution of Egypt's Coptic Christians," 2013).

In February 2014, ICC noted that a number of Christians, including children, were kidnapped in the Minya Province of Upper Egypt, and that Christians were increasingly taken and held for ransom ("Kidnappers Target Christian Children in Egypt | Persecution," 2014). Additionally, ICC states that security forces in the region have been ineffective in preventing such attacks against Christians. Fast forwarding to 2017, we note that the situation has not improved as exemplified by the attack on buses escorting Christians to the Saint Samuel Monastery in Minya Province in May, 2017. According to the magazine Foreign Policy:

A group of masked gunmen opened fire on Coptic Christians in southern Egypt Friday, killing at least 26 and wounding 25. As many as 10 attackers in three pickup trucks intercepted buses of Coptic Christians near the city of Minya, some 130 miles south of Cairo, and gunned them down before fleeing the scene. The victims were en route to the Saint Samuel Monastery in Minya province. (Gramer, 2017)

Five months later in October 2017, Copts were attacked at a recently renovated church. The church was attacked by a mob of nearly 1,000 . What was most alarming about this incident was that the Egyptian Government blamed the Christian community, who were forced to sign a "peace agreement." As reported by The Express:

More than 1,000 people gathered outside a recently-renovated Coptic church in Mina, Egypt, to intimidate and threaten those inside. Police were called on October 26 and the doors of the Saint George Church, as well as the on-site children's nursery, was bolted shut for defence. Despite the aggression of the crowd, it was the Copts who were held responsible for the incident. The heads of the Coptic congregation in the area were forced into attending a peace meeting, which aimed to stop the conflict between the group and the local Muslim community. A source close to the church said: 'Copts had to agree to the reconciliation that will be held this evening in the village hall. A written agreement was presented that indicated a framework of friendliness, love and brotherhood. A reconciliation and 
waiver of all records between the two sides must be signed, including a 'non-provoke crisis' clause (Millar, 2017).

The following month, further attacks ensued. On December 29, 2017, another church was attacked, this time in Cairo. As the New York Times reported:

At least nine people were killed when gunmen opened fire on a Coptic Orthodox Church in Cairo on Friday, a church spokesman said, in the latest in a series of attacks on Egypt's Christian minority. The assault targeted the Mar Mina Church in the southern Cairo neighborhood of Helwan. At least one gunman was killed by the police, the spokesman, Boules Haliem, said by telephone. 'He did not manage to get in,' Mr. Haliem said of the gunman. Worshipers were attacked as they were leaving the church, he said, and at least eight were killed, along with one police officer. Eight more worshipers and a police officer were wounded ("Gunmen Attack Cairo Church, Killing at Least 9," 2017).

Reporting on the continuing dismal conditions facing Christians in Egypt, Open Doors International ranked Egypt number 17 on its 2018 World Watch List of the world's biggest violators of religious rights. This is up five spots from 2016, when Egypt ranked number 22 ("World Watch List | Countries Where Christianity is Illegal \& Oppressed," n.d.). Open Doors International blames some of the violence on the political uncertainty in the country, which create space for sectarian clashes.

These reports show that the situation in terms of religious freedom in Egypt is not improving. Moreover, that the Egyptian Government has been complicit in the oppression of Christians, giving religious extremists the ability to persecute Christians without any negative consequences and/or punishment for such acts. Often this oppression comes as an appeal for Christians to ignore the crimes of Muslims against them, as this quote indicates:

When Muslims attack Christians and murder some of them, burn out churches, or seize some of their lands, the Egyptian government, in the name of national unity, appeals to the Copts to withhold protest or attempts to seek justice. The Copts out of their concern and loyalty to their country accept the situation until further incidents or crimes take place. The government again appeals to the goodwill of the Copts. These lies and deceit from the government have led Copts to their present situation, where they are now unsafe in their land and unable to assert their rights. This circle of violence continues daily throughout the country. Muslims and the government slap 
Copts in the face, and ask Copts to forgive for the sake of peace in the city or town where the crime takes place.... Most [incidents] are not reported to the police, or to any other legal entity in the country, because those attacked fear being victimized again by these entities. (Bistawros, 1974)

The Egyptian Constitution upholds freedom of belief and the practice of religious rites. However, in practice the Egyptian Government places restrictions on these rights. The Constitution provides that Islam is the official state religion of the country and the primary source of legislation. Religious practices that conflict with Islamic law, Shari'a, are prohibited. Although neither the constitution nor the civil and penal codes prohibit proselytizing or conversion to another religion from Islam, the government discourages proselytizing by non-Muslims, and those who do so risk prosecution under the Penal Code, which prohibits citizens from ridiculing or insulting heavenly religions or inciting sectarian strife.

\section{Christians and Extremism in Egypt:}

Although President al-Sisi considers himself to be Egypt's strong arm when it comes to combating extremist terrorist acts, they have continued plagued the country. Christians have been the principal targets of this extremist terrorism. Exemplifying this targeting, on April 9, 2017 - Palm Sunday - ISIS claimed responsibility for a string of attacks on Christian places of worship. In total, the attacks resulted in 44 deaths and over 100 injured ("Palm Sunday attacks: 44 dead, more than 100 injured in church bombings carried out by ISIS in Egypt," 2017). These combined attacks represented the deadliest single day in decades aimed at Christians in Egypt, which caused President al-Sisi to call for a three-month state of emergency ("Egypt Declares State of Emergency, as Attacks Undercut Promise of Security," 2018). Christians, however, are not the only group affected by terrorism in the country. Currently, the country is seeing a surge in terrorist activity in the Sinai Peninsula, where Islamic extremist groups have been targeting government forces, as well as religious minorities. According to a New York Times report on November 24, 2017:

Militants detonated a bomb inside a crowded mosque in the

Sinai Peninsula on Friday and then sprayed gunfire on panicked worshipers as they fled, killing at least 305 people and wounding at least 128 others. Officials called it the deadliest terrorist attack in Egypt's modern history. ("Militants Kill 305 at Sufi Mosque in Egypt's Deadliest Terrorist Attack," 2018)

The question is to what extent can President al-Sisi - and his government - actually protect minorities like Christians in Egypt? Is he even 
willing and able to do so? Magdy Samaan and Declan Walsh of The New York Times gave the following insights:

Security is the central promise of Mr. Sisi, a strongman leader who returned on Friday from a triumphant visit to the United $\underline{\text { States, }}$ where President Trump hailed him as a bulwark against Islamist violence. Mr. Trump made it clear that he was willing to overlook the record of mass detention, torture and extrajudicial killings during Mr. Sisi's rule in favor of his ability to combat the Islamic State and defend minority Christians...Sunday's bloodshed underscores the difficulty of stopping suicide attacks. More starkly, it highlighted the failure of Egypt's powerful intelligence agencies to anticipate a coordinated wave of devastating attacks. ("Egypt Declares State of Emergency, as Attacks Undercut Promise of Security," 2018)

\section{The Cases: Part II:}

Given the above, we can now return our attention to the individual cases presented at the beginning of this paper in order to demonstrate how religious intolerance affects people on a personal level. Mr. Lukman's case, which is more general, reflects the above documentation on the overall treatment of Christians in the country. A closer look, however, at Mr. Masud and Ms. Shani, we note that they are affected in additional ways.

Mr. Masud faced threats from his own family members due to his religious beliefs. As noted, Mr. Masud was punished severely as a child for not taking Islam seriously, and was expelled from his courses. It was then that he began his interest in, and eventual conversion to Christianity. This brought the ire of his family, including death threats. This is not uncommon in Egypt. Mr. Masud suffered violence at the hands of his family and a possible "honor killing".

Honor killing is defined by Human Rights Watch as the "murder of a person, usually a woman, suspected of having offended the honor of the family or community, generally on the basis of sexual behavior deemed transgressive - for example, engaging in a sexual relationship outside of heterosexual marriage ("Human Rights Watch," n.d.). In Egypt, "honor" violence is not limited to women, as both men and women who are deemed as bringing shame to the family are condemned. This is true in both urban centers and rural areas, as tribal customs permeate all of society. According to Fadia Faqir, a Jordanian-born British author, writing for Third World Quarterly:

Within urban centres the honour of the individual is related to that of the family, but in rural areas the honour of the individual has wider connotations and is related to that of the family, clan, community and tribe. Tribal law, or 'urf', considers honour as 
something that does not belong to one individual, but to the whole community. This honour of the females (and males) of the tribe has to be safeguarded through the following measures: the protection and defence of the honour of all members, both male and female, and the imposition of serious penalties on those who threaten the honour of the tribe and all its members. (Faqir, 2001)

In a report issued by the New York Times, roughly 5,000 cases of honor killings take place each year in predominately Muslim countries (Zoepf, 2007). Egyptian laws do not appropriately penalize this practice nor does the Islamic law. This is due in large measure to the "tribal system and popular beliefs about sexuality. In addition, modern penal codes and also the practices reinforce the notion that men have a 'right' to punish individuals for improper sexual behavior" (Stop Stoning, n.d.). According to an expert paper issued by the United Nations:

Article 17 of the Egyptian Penal code allows judges to decrease the sentences given in the case of murder when they decide that the condition of the murderer requires so. Such reductions reach as little as six months that could also be spent during the trial. Therefore, the murderer can escape being imprisoned and walks free (Khafagy, Fatma, 2005)

The UN report notes that the practice of "honor" killing is growing in popularity in contemporary Egypt, supported by a strong wave of conservatism throughout both rural and urban areas. Recent Egyptian films depict the practice as part of a highly respected and valued tradition, with family honor shown as dependent upon sexual purity. Consequently, any criticism, promoted primarily by activists, of the practice is rejected by most in mainstream society:

They consider activists who condemn the practice as deviants from the religious principles and from good traditions and that they are only attempting to adopt a western agenda that does not respect family's honour and that permit females to practice premarital and extra marital relationships. (Khafagy, Fatma, 2005)

In its collection of data, the UN has over the years monitored both the prevalence of "honor" killings, as well as the manner in which and by whom they have been committed. The report finds that:

Information collected showed also that means used in honour killing ranged from strangling, burning, forcing the individual to take poison, or throwing them from the window. ... it was found that in many cases the murderer admits quickly the crime to the police because he feels proud of his act and believes that 
his tribe or community should know and value what he has done. Mothers sometimes commit honour crimes and kill their daughter especially in cases of daughters having pre-marital relations and having become pregnant (Khafagy, Fatma, 2005).

Mr. Masud had reason to fear that he likely would have been targeted for violence by his uncle or by other members of his extended family, or clan, or by one or more of the many Islamist fundamentalists in Egypt encouraged by an Imam's fatwa, because of his religious conversion. Given reports issued by the U.S. State Department, the United Nations, and by other organizations such as Amnesty International and Human Rights Watch that monitor the issue of honor killing in Egypt and the greater Muslim world, Mr. Masud fears of returning to Egypt were indeed well founded.

While the major focus of "honor" killing studies has been primarily on women, men in the Muslim world are increasingly being targeted by family members for bringing shame upon the family. Consequently, many scholars in the field have updated and expanded the definition of "honor" crime. According to Linda Carbonell:

Honor killings are not...exclusively practiced against women....In modern Muslim nations, honor killings [occur against] homosexual behavior and sexual activity - including dating - out of wedlock, outside of social class or sectarian boundaries, across [sic] religious lines or without proper male supervision. The more fundamental and traditional the family and group, the greater the possibility of an honor killing. The more isolated the community, the less possibility of detection and arrest. (The Pillar of Information," n.d.)

Additionally, the tightly knit society that exists in Egypt made it virtually impossible for Mr. Masud to live anywhere in Egypt in peace. Family networks run throughout the country and across provincial lines between communities. The very nature of such a society - where anonymity is simply not possible - precludes any situation where he could have hidden permanently. The situation was made even grimmer given Mr. Masud's uncle's high-ranking position in the military. Moreover, in tribal-based cultures such as Egypt's there is no concept of a "statute of limitations" when it comes to extralegal "honor" violence. Mr. Masud could return to Egypt in one, five, ten, or twenty years, and the situation for him would not be changed. Consequently, should he ever return, he would still face a threat to his life similar to the one he currently faces as "honor" violence extends across generations.

Ms. Shani faced many of the same dangers and obstacles in her own experience. However, as a woman helping her friend escape a forced marriage and forced conversion, her resources and options were limited. After facing 
numerous threats and beatings, she had only her family to rely on for support. She was forced into hiding, as society at large deemed her an infidel, and demanded blood as punishment. Even as Ms. Shani stated that she attempted to lay low and moved from one location to another, she was always in danger as word spread about her religious beliefs and her actions. Like Mr. Lukman and Mr. Masud, Ms. Shani was eventually forced to flee the country.

\section{Conclusion:}

Mr. Lukman, Mr. Masud, and Ms. Shani all faced overwhelming obstacles and extreme danger had they not been allowed to remain in the United States. The threats confronting their survival and well-being in Egypt emanated from numerous directions. Each of them provided unique narratives describing the actual socio-political conditions Christians suffer in Egypt. While their backgrounds are different, they share one commonality - Christianity.

As the uncertainty grows over Egypt's transitional period in terms of politics, one thing remains certain, that socio-political conditions facing historically persecuted individuals including Baha'is, Coptic Christians, apostates and other groups deemed to be pariahs in society are only expected to worsen in the coming months and years. It is important to keep in mind that while the government of Egypt is in turmoil, societal norms and expectations remain the same. Throughout Egypt religiously and politically motivated attacks are common. Violent political and religious extremists are increasingly able to act with impunity. The Egyptian Government has been unable or unwilling to effectively curtail the abuses suffered by non-Muslim groups and individuals in Egypt. Egyptian police authorities either ignore the abuses or exacerbate them by aiding extremists. The Egyptian security forces and police have been complicit in the violation of human rights in general, including the well documented sustained use of torture.

Egypt is a nation driven in large part by Shari'a Law. Throughout this paper there has been an ongoing analysis of the importance of Islam in Egyptian society and culture, and how its deeply respected and entrenched societal values are manifested in the law. Given the primacy of Islam in Egypt, we can begin to understand the fears shared by Mr. Lukman, Mr. Masud, and Ms. Shani.

Despite claims by the Government of Egypt that it respects and protects religious freedom, we are currently witnessing a time in which nonMuslims are marginalized and often de facto subjected to the rulings of Shari'a law. It is the opinion of this analysis that such actions do not represent religious freedom, but rather demonstrate intense efforts by the Egyptian authorities to promote an air of national unity at the expense of religious minority groups, particularly at the expense Christians in the country. 


\section{References:}

1. Abdelmassih, M. (2009, June 6). U.S. Copts Association. Retrieved from http://www.copts.com/english/?p=3657\#more-3657

2. The Associated Press. (2010, January 6). Attack at a Church in Egypt Kills $7 . \quad$ Retrieved from http://www.nytimes.com/2010/01/07/world/middleeast/07egypt.html ?_r=1\&scp=6\&sq=Copts\%20January\%206\&st=cse

3. Atheists around world suffer persecution, discrimination: report. (2012, December 10). Retrieved from http://www.reuters.com/article/2012/12/10/us-religion-atheistsidUSBRE8B900520121210

4. Attacks on Egypt's Copts Escalate | National Review. (2011, January 3). Retrieved from http://www.nationalreview.com/corner/256207/attacks-egypts-coptsescalate-paul-marshall

5. Bistawros, B. T. (1974). The Coptic Christians Of Egypt Today: Under Threat of Annihilation(Unpublished master's thesis). Robertson School of Government, Regent University, Virginia Beach, VA.

6. Christian Girl Abducted In Egypt | Persecution. (2013, February 6). Retrieved from http://www.persecution.org/2013/02/06/christiangirl-abducted-in-egypt/

7. Egypt blogger guilty of blasphemy. (2012, December 12). Retrieved from http://www.bbc.com/news/world-middle-east-20695992

8. Egypt Declares State of Emergency, as Attacks Undercut Promise of Security. (2018, January 20). Retrieved from https://www.nytimes.com/2017/04/09/world/middleeast/explosionegypt-coptic-christian-church.html?_r=0

9. Egyptian Christian Girl, 13, Abducted By Muslims. (n.d.). Retrieved from http://www.aina.org/news/20130202195322.htm

10. Egyptian Copts seek Russian refuge. (2013, February 11). Retrieved from http://www.bbc.co.uk/news/world-europe-21418264

11. Egypt's Bloody Sunday | Middle East Research and Information Project. (n.d.). Retrieved from http://www.merip.org/mero/mero101311

12. Encyclopedia Coptica: The Christian Coptic Orthodox Church Of Egypt. (n.d.). Retrieved from http://www.coptic.net/EncyclopediaCoptica/

13. Faqir, F. (2001). Intrafamily femicide in defence of honour: The case of Jordan. Third World Quarterly, 22(1), 65-82. doi:10.1080/713701138 
14. Gramer, R. (2017, May 26). Dozens of Coptic Christians Gunned Down in Egypt Attack. Retrieved from http://foreignpolicy.com/2017/05/26/egypt-coptic-christiansattacked-middle-east-minority-persecution-north-africa/

15. Gunmen Attack Cairo Church, Killing at Least 9. (2017, December 30). Retrieved from https://www.nytimes.com/2017/12/29/world/middleeast/egyptchurchattack.html?rref=collection\%2Ftimestopic\%2FEgypt\&action=click \& contentCollection $=$ world $\AA$ ion $=$ stream\& module $=$ stream unit\&vers ion $=$ latest $\&$ contentPlacement $=5 \&$ pgtype $=$ collection

16. Human Rights Watch. (n.d.). Retrieved from http://hrw.org/reports/2008/turkey0508/turkey0508web

17. International Religious Freedom Report for 2016. (n.d.). Retrieved from

http://www.state.gov/j/drl/rls/irf/religiousfreedom/index.htm\#wrappe $\mathrm{r}$

18. Khafagy, Fatma. (2005). Honour killing in Egypt: Expert paper. Cairo, Egypt: Association of Legal Aid for Women.

19. Kidnappers Target Christian Children in Egypt | Persecution. (2014, February 15). Retrieved from http://www.persecution.org/2014/02/16/kidnappers-target-christianchildren-in-egypt/

20. Lez Get Ideas - The Pillar of Information. (n.d.). Retrieved from http://lezgetreal.com/2011/09/honor-killing-in-jordan/

21. Militants Kill 305 at Sufi Mosque in Egypt's Deadliest Terrorist Attack. (2018, January 20). Retrieved from https://www.nytimes.com/2017/11/24/world/middleeast/mosqueattack-egypt.html

22. Millar, J. (2017, November 18). Horror as 1,000-strong mob attacks CHURCH forcing Christians to lock themselves inside. Retrieved from https://www.express.co.uk/news/world/880651/copts-egyptcoptic-christian-persecution

23. Muslim Villagers in Egypt Attack Church - Morningstar News. (2013, February 22). Retrieved from http://morningstarnews.org/2013/02/muslim-villagers-in-egyptattack-church/

24. Palm Sunday attacks: 44 dead, more than 100 injured in church bombings carried out by ISIS in Egypt. (2017, April 9). Retrieved from http://www.foxnews.com/world/2017/04/09/egypt-churchbombing-kills-at-least-21.html 
25. The persecution of Egypt's Coptic Christians. (2013, December 13). Retrieved from http://www.cbsnews.com/news/persecution-ofegypts-coptic-christians/

26. Religious intolerance in Egypt. (n.d.). Retrieved from http://www.religioustolerance.org/rt_egypt.htm

27. Republican Congressman Frank Wolf: Coptic Christians Fear for Their Future in Morsi's Egypt. (2013, March 10). Retrieved from http://www.christianpost.com/news/republican-congressman-frankwolf-coptic-christians-fear-for-their-future-in-morsis-egypt-91566/

28. Stop Stoning. (n.d.). Frequently Asked Questions About Honor Killings. Retrieved from stop-stoning.org/node/12

29. The Washington Post. (2013, March 19). Retrieved from http://www.washingtonpost.com/world/middle_east/muslims-attackchristians-in-egypts-south-over-allegations-that-girl-wasabducted/2013/03/19/b9135316-90d7-11e2-91737f87cda73b49_story.html

30. U.S. Copts Association. (2018, May 21). Retrieved from http://www.copts.com/english/?p=3657\#more-3657

31. Welcome to Pharos. (n.d.). Retrieved from http://pharos.bu.edu/cn/articles/CoptsThroughTheAges.txt

32. World Watch List | Countries Where Christianity is Illegal \& Oppressed. (n.d.). Retrieved from https://www.opendoorsusa.org/christian-persecution/world-watchlist/

33. Zoepf, K. (2007, September 23). Syria - Honor Killings - Zahra alAzzo.

http://www.nytimes.com/2007/09/23/magazine/23wwln-syriat.html?pagewanted $=1 \&$ sq 